\title{
Use of flyash to improve soil properties of drinking water treatment sludge
}

\author{
Udeni P. Nawagamuwa* and Nipuna Wijesooriya
}

\author{
*Correspondence: \\ udeni@uom.lk \\ Department of Civil \\ Engineering, University \\ of Moratuwa, Moratuwa, Sri \\ Lanka
}

\begin{abstract}
Improvement of soft soil using cementitious additives is a widely practiced technique in the construction industry. However, cement mixing is considered to be an expensive technique and this research has attempted to study the use of an industrial waste; flyash to improve a drinking water treatment sludge. Flyash is a fine, glass powder recovered from the gases of burning coal during the production of electricity at Norochchole, thermal power plant in Sri Lanka. The larger amount of drinking water treatment sludge which is a very soft clayey soil, is disposed into the environment without acquiring any benefit. Use of flyash in improving soft soils such as sludge with a low maximum dry density and low CBR will solve few burning issues such as dumping of flyash and sludge, health issues due to disposal of flyash and sludge, difficulties to find soils with better properties for road constructions and other construction related applications. Identifying the characteristics of the sludge, studying the variation of maximum dry density and optimum moisture content with flyash content, strength gain with time, and the applicability of the improved soil in the industry are the key findings and observations of this study. It was observed that the optimum proportion of the flyash to be added to the sludge to achieve a remarkable gain in its properties is around $30 \%$ of its dry weight. Acceptable CBR value was achieved after 7 days curing followed by standard 4 days soaking period.
\end{abstract}

Keywords: Flyash, Sludge, Soft soil improvement, Maximum dry density, CBR

\section{Introduction}

One of the most demanding issues in civil engineering constructions is unavailability of suitable soils for applications such as highway, and railway construction and land filling. Poor bearing capacity, low shear strength, and high compressibility are some of the key issues that generally arise in road and other construction sectors with a poor soil. The most common solution for these issues is removing the weak soil and refill it with a good soil. However, this will be time consuming and costly and very importantly dumping of poor soil is not environmental friendly. Further, a serious environmental damage will occur due to excavation of new soils for refilling. Therefore, a reasonable option to overcome this issue is to improve the existing soil using appropriate additive materials.

Additions of foreign materials are being used to improve weak soils as binders [20]. As an example; cement is a good additive to improve the characteristics of weak soils with low bearing capacity and shear strength. However, this is considered as a very expensive methodology for a developing country like Sri Lanka. Therefore, many research studies 
were done in order to study the possible improvements of such poor soils with industrial wastes such as flyash (wastes from thermal power plants), and copper slag (wastes from harbor and port sector) etc. This will be a cost effective and environmental friendly approach while reducing the carbon foot print in new development projects.

Water treatment plants in Sri Lanka apply the processes of coagulation, flocculation, sedimentation, filtration and disinfection to treat raw water. Aluminum sulfate or alum is commonly used as a flocculent to remove unwanted colour and turbidity from original drinking water sources, mainly from the water rich rivers in the country. Colloidal and suspended materials such as sand, silt and clay along with humic particles present in the crude water will be removed by neutralization, floc mechanism and adsorption onto hydroxide precipitates. These precipitates and soil particles are removed from the raw water and that semi solid slurry is called sludge [1,21]. This sludge is either discharged or dumped into the landfills. However, it was noted that Rodriguez et al. [19] had discussed the use of spray-dried sludge from drinking water treatment plants as a prime material for clinker manufacture highlighting the benefits of sludge.

Present study was conducted to improve a sludge collected from a water treatment plant near Kalu river in Horana, Kalutara and the additive material is flyash, which is fine, glass powder recovered from the gases of burning coal during the production of electricity at Norochchole, thermal power plant in Sri Lanka. After improving such soft soils, those can be used for various development projects such as road projects, embankments, construction sites and land filling (playgrounds, recreational areas, etc.) depending on the level of improvements achieved due to the addition of flyash $[14,15,18]$.

Many literature findings indicate that properties of soft soils would improve when flyash is used as an additive. Karim et al. [13] emphasized the need of reusing flyash as a construction material, because, the disposal of flyash is an environmental concern [16]. Both high and low calcium class $C$ flyashes could be used as effective stabilizing agents for improving expansive soils as recommended by Cokca [10]. Bhuvaneshwari et al. [8] concluded that when the flyash percentage was $25 \%$, workability had been at the maximum for stabilization of expansive soils with flyash. Phani Kumar and Sharma [18] reported that with the increase of flyash content, there is a reduction in optimum moisture content while increasing maximum dry density.

\section{Methodology}

Sludge samples collected in semi solid form from the water treatment plant in Horana and flyash collected from Norochchole in powder form were kept in the oven until they become completely dry. Those particles were then tested to find out the particle size, Atterberg limits, standard Proctor compaction tests and CBR tests. Oven dried sludge and flyash were mixed, to prepare samples by changing their mix proportions. This was done manually until the mixture becomes uniform. Seven samples were prepared on the dry weight basis as given in Table 1.

Table 1 Proportions of the mixed samples

\begin{tabular}{|c|c|c|c|c|c|c|c|}
\hline Soil \% & 100 & 90 & 80 & 70 & 60 & 50 & 0 \\
\hline Flyash \% & 0 & 10 & 20 & 30 & 40 & 50 & 100 \\
\hline
\end{tabular}


Having prepared the samples, standard Proctor compaction tests (ASTM D 698-78 [4]) were carried out for each sample. Then, maximum dry density and optimum moisture content of each sample were obtained by plotting the relationship between the dry density and moisture content. With those results, the relationship between maximum dry density (MDD) and optimum moisture content (OMC) with flyash content was obtained. The best proportion which delivers the maximum dry density was selected as the optimum mix proportion. Then the Atterberg limit tests (ASTM D 4318-83 [3]) were carried out to determine the plasticity properties on this selected composition.

Since flyash is a cementitious material, it will gain strength with time due to its pozzolonic action [12]. California Bearing Ratio (CBR) tests (ASTM D 1883-73 [6]) were conducted on flyash mixed sludge samples to identify the strength gain with time. The selected optimum proportion between sludge and flyash was used for preparation of samples for CBR test. One sample was prepared using unimproved sludge as a control sample and relevant optimum water content was obtained by conducting Proctor density tests on sludge. Three samples were prepared according to the selected proportion and water content which was obtained from the plot between the optimum moisture content and flyash percentage.

Two samples out of these three samples were cured using sprinklers and wet gunny bags. One was up to 7 days and the other was up to 28 days. After curing, those two samples were soaked 4 days to measure CBR values. Sample preparations and experimental work were conducted according to the ASTM standards mentioned in Table 2 during the laboratory studies. Similar methodology was followed to measure the CBR values of the control samples after 7 and 28 day curing.

\section{Results}

\section{Properties of sludge}

The sludge used in this study was collected from a water treatment plant located in Horana, Kalutara district, Sri Lanka. Figure 1 and Table 3 provide the particle size distribution and key findings of the sludge, respectively.

Further, it was observed that liquid limit, plastic limit and plasticity index of sludge Were, 59.44, 51.75 and $7.69 \%$ respectively. Specific gravity of the sludge was 2.36 . According to the Unified Soil Classification System (USCS), sludge could be classified as MH and according to ASTM D 2487-11 [7], it is described as an elastic silt. Then the standard Proctor compaction test was conducted on sludge. Maximum dry density was $1116 \mathrm{~kg} / \mathrm{m}^{3}$ at the optimum moisture content of $34 \%$. These observations are plotted along the compaction results of flyash as shown in Fig. 2. The 4 day soaked CBR Test on

Table 2 Standards maintained during the laboratory tests

\begin{tabular}{ll}
\hline Test & Testing method \\
\hline Particle size distribution & ASTM D 422-63 \\
Liquid limits (LL) (\%) and plastic limit (PL) (\%) & ASTM D 4318-83 \\
Maximum dry density & ASTM D 698-78 \\
Specific gravity & ASTM D 854-83 [5] \\
California bearing ratio (4 days soaked) & ASTM D 1883-73 \\
\hline
\end{tabular}




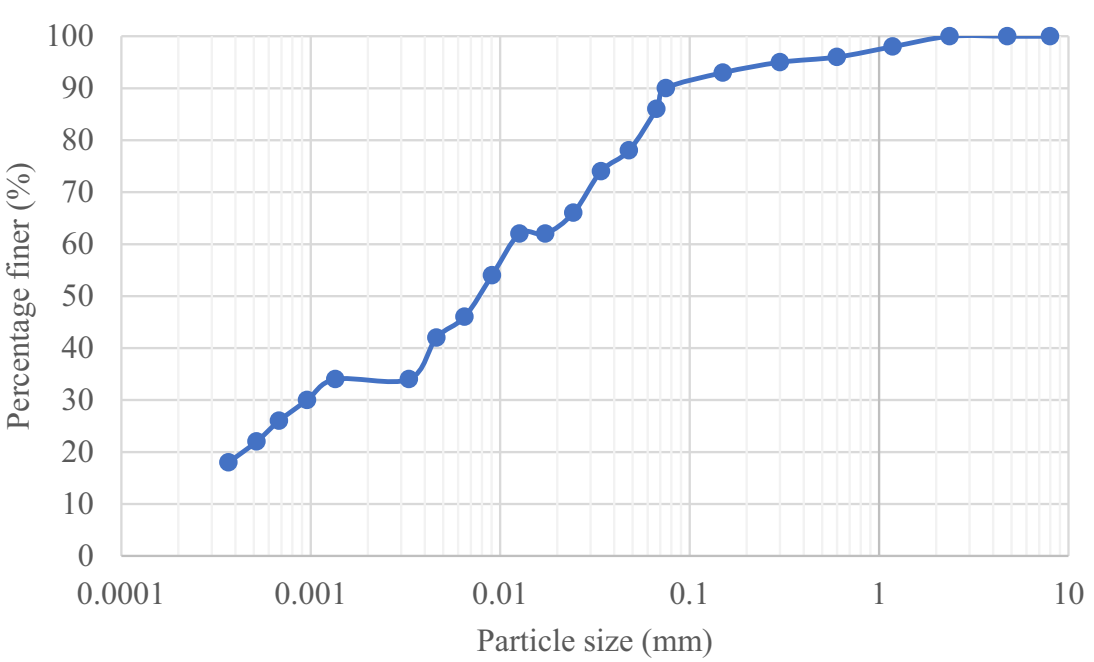

Fig. 1 Particle size distribution of sludge [2]

Table 3 Properties of sludge

\begin{tabular}{llll}
\hline Organic content (\%) & \multicolumn{2}{l}{ Grain size distribution } & \\
\cline { 2 - 4 } & Gravel (\%) & Sand (\%) & Silt and clay (\%) \\
\hline 19.32 & 00 & 10 & 90
\end{tabular}

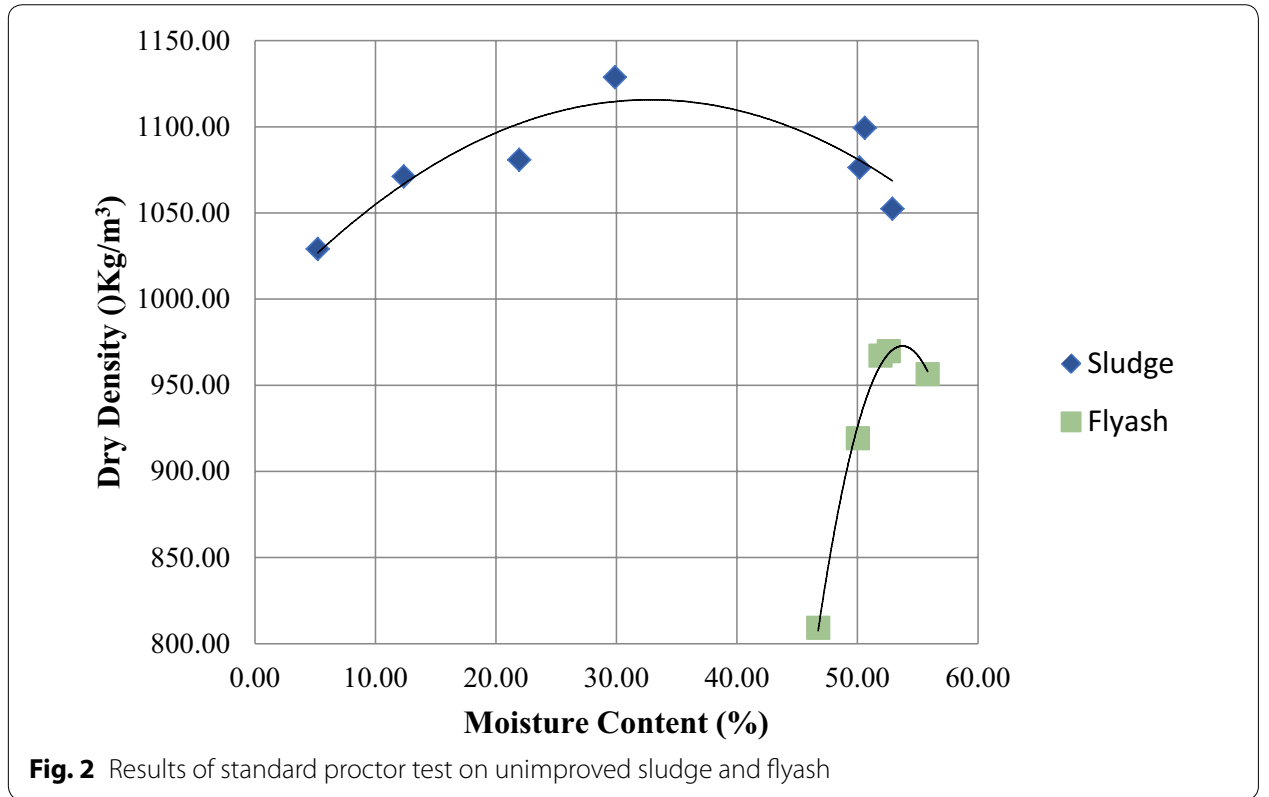

this unimproved sample provided very low values of $4.09 \%$ of the top and $4.85 \%$ at the bottom.

According to the standard Proctor compaction test results, maximum dry density of flyash was obtained as $975 \mathrm{~kg} / \mathrm{m}^{3}$ and the optimum moisture content was $53.6 \%$. The 
specific gravity was 2.27 . Due to non plastic nature, plastic limit and the plasticity index values could not be determined.

\section{standard proctor compaction test results on flyash mixed sludge}

Figure 3 illustrates behavioural differences of Proctor density results on different mix proportions of flyash and sludge. Table 4 provides the summary of maximum dry density (MDD) values for those different mix proportions.

While increasing the flyash content, MDD increases up to a peak at flyash content of $30 \%$ as shown in Fig. 4. Thereafter, with further increasing of flyash content, maximum dry density decreases. Corresponding OMC values for different mix proportions are shown in Fig. 5. Similar observations were made by Nawagamuwa and Prasad [17] for the studies done on rejected lateritic soils due to poor CBR values improved with flyash for road sector applications.

Since, best suitable value to achieve the highest MDD was obtained with the proportion of flyash $30 \%$, further tests were carried out with that particular condition. This result is comparable with Brooks [9] and it was reported that the most effective flyash content for improving engineering properties were in the range of $15-30 \%$.

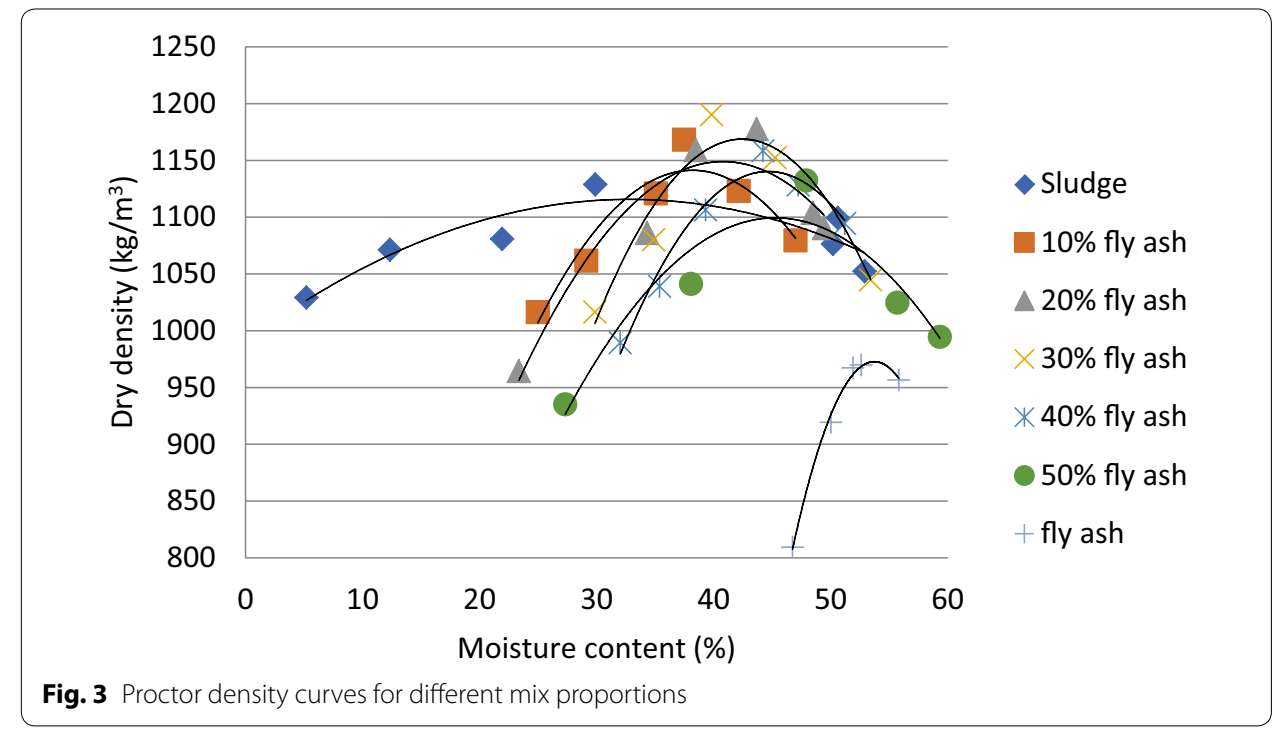

Table 4 MDD values for different mix proportions of flys ash and sludge

\begin{tabular}{lcc}
\hline Flyash percentage (\%) & Sludge percentage (\%) & MDD $\left(\mathbf{k g} / \mathbf{m}^{\mathbf{3}}\right)$ \\
\hline 0 & 100 & 1116 \\
10 & 90 & 1141 \\
20 & 80 & 1150 \\
30 & 70 & 1170 \\
40 & 60 & 1140 \\
50 & 50 & 1100 \\
100 & 0 & 975 \\
\hline
\end{tabular}




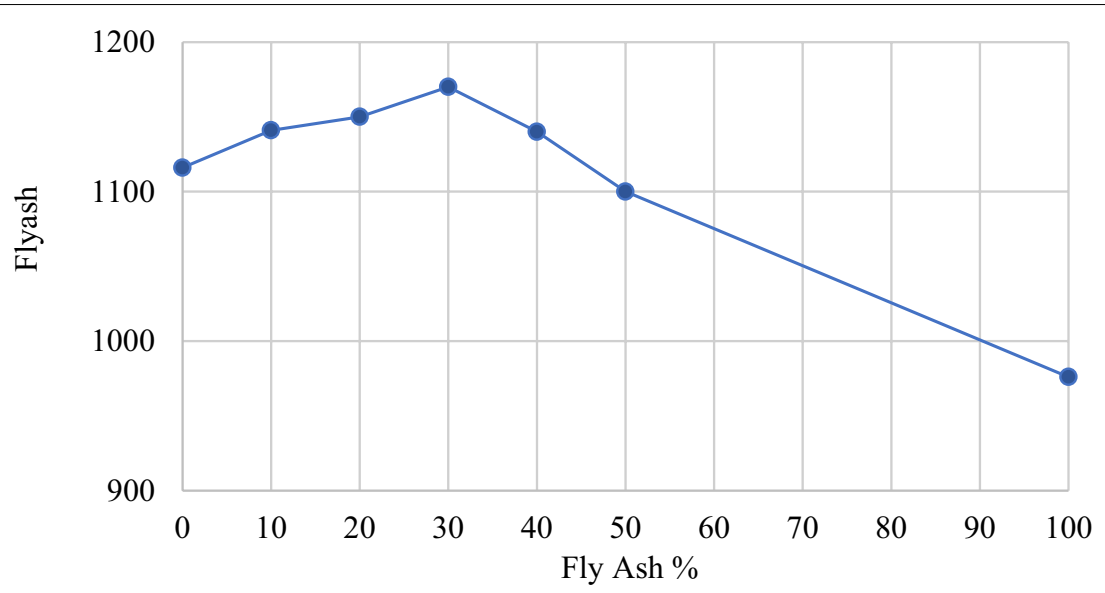

Fig. 4 Variation of maximum dry density with Flyash content

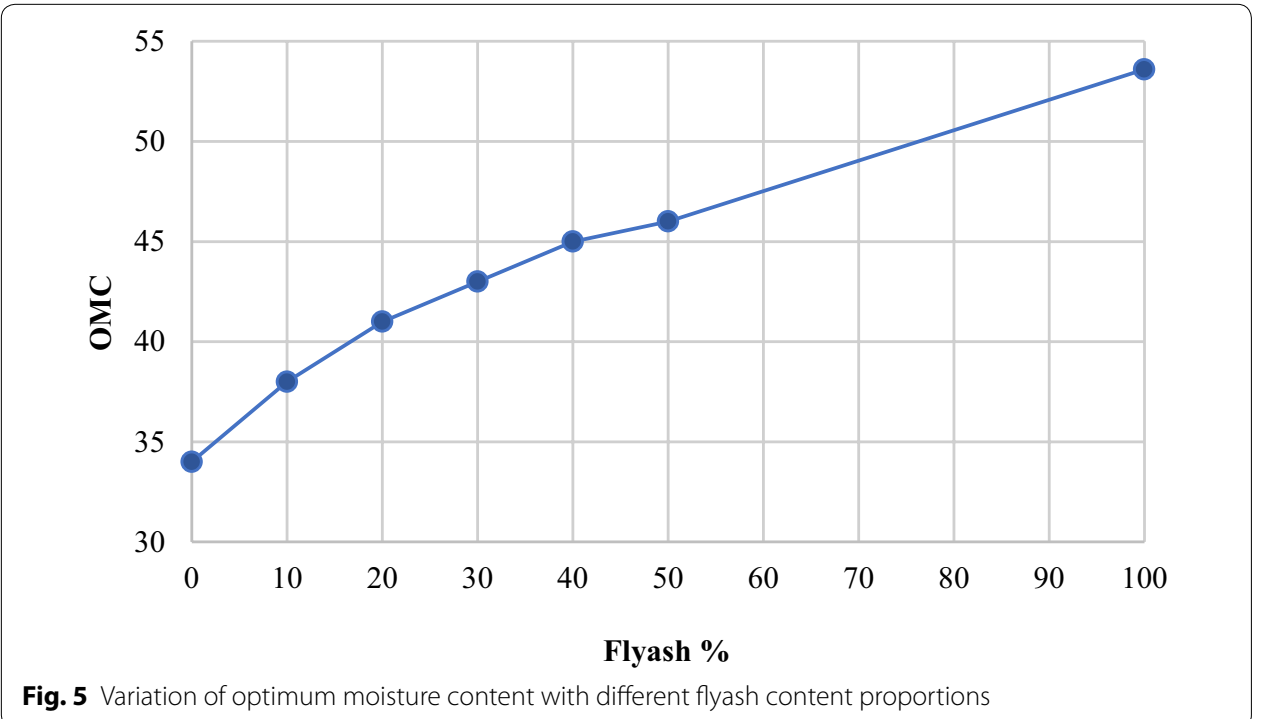

Liquid limit for the mix proportion with $30 \%$ of flyash was $52.1 \%$. Plastic limit and plasticity index were 45.51 and $6.51 \%$ respectively.

\section{California bearing ratio (CBR) test results on the improved sludge}

Four day soaked CBR tests were conducted on sludge without any additives and improved with $30 \%$ of flyash. To identify the behavior of flyash with time, CBR tests were carried out on the samples with $30 \%$ of flyash in sludge and these samples were kept for curing for 7 and 28 days prior to 4 days soaked CBR testing. Those results are summarized in Table 5 and Fig. 6.

Figure 6 clearly exhibits that the curing period prior to 4 days soaked CBR tests has increased the CBR values. This increment is around $300 \%$ of the unimproved sludge. However, a noticeable gain is not visible due to additional curing from day 7 to day 28 . 
Table 5 Variation of CBR value of improved sludge with $30 \%$ flyash according to curing time

\begin{tabular}{llr}
\hline Days & Bottom \% & Top \% \\
\hline 0 & 16.89 & 11.36 \\
7 & 20.08 & 13.26 \\
28 & 20.83 & 14.39 \\
\hline
\end{tabular}

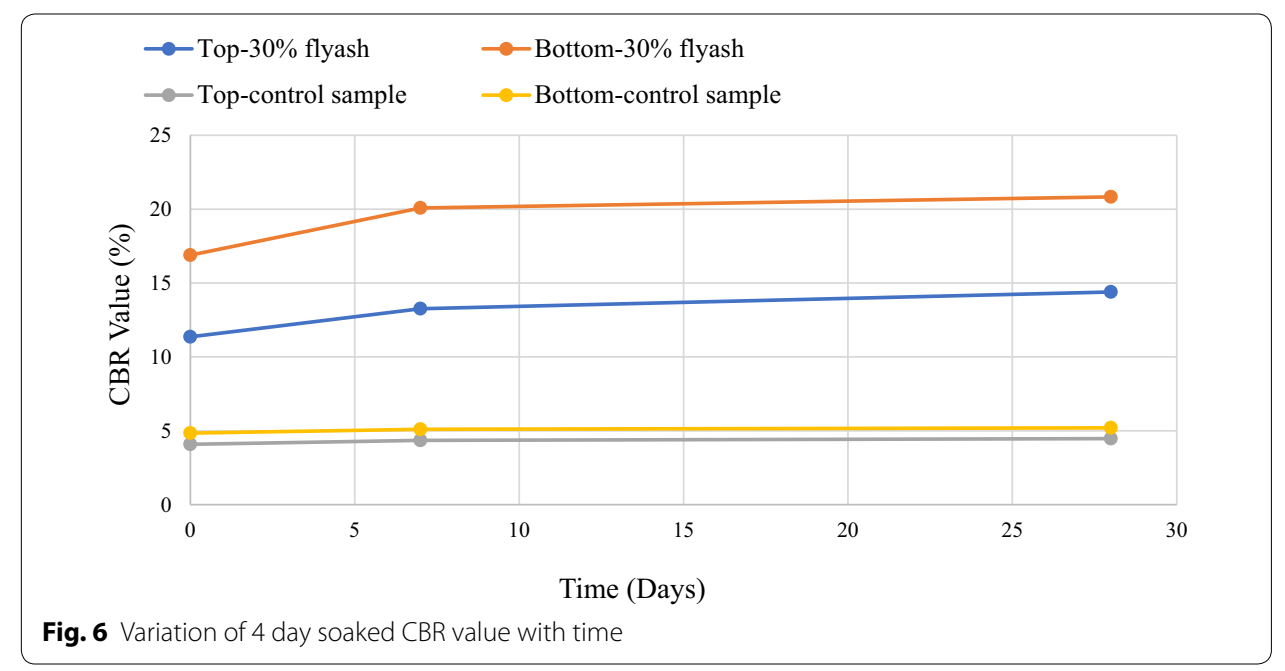

\section{Conclusion}

Soils with lower CBR values are rejected in most of the civil engineering field works such as road and construction sector applications. Therefore, the soil has to be either improved or removed. Removing and refilling will definitely disturb the natural environment and increase the project cost. There are large number of water treatment plants in Sri Lanka which end up in an excess amount of sludge in the treatment process as a residue. This sludge is considered as a waste and hence dumping is a critical issue. Flyash is also another industrial waste generated in the thermal power plant in Sri Lanka. This attempt was made to make use of both sludge and flyash in a productive manner. Also, the proposal of mixing sludge with flyash could be considered as a cost effective and environmentally friendly solution for two problematic dumping issues in the country.

This study concludes that lower CBR soils such as sludge can be enhanced with flyash with an optimum value at $30 \%$. Although there was a less considerable increment of MDD on as-mixed samples, a noticeable high improvement of CBR values was observed compared to an unimproved sludge after 28 day curing. However, this enhancement is not yet satisfactory to ICTAD [11] specifications applied in the country to be used in the road sector applications with liquid limit $<40 \%$, plasticity index $<15 \%$, MDD $>1750 \mathrm{~kg}$ / $\mathrm{m}^{3}$ and $\mathrm{CBR}>30 \%$. It has to be noted that some of these conditions were tested at the as mixed state and not with the improved stage with time. Therefore, this improved sludge cannot be used in the road sector without further improvement. However, there are other applications for this kind of soils such as a low weight land filling for different 
purposes. Proper mixing of sludge and flyash can be obtained using a conveyor belt and a hopper system in the field with appropriate moisture content.

\section{Authors' contributions}

NW carried out the laboratory studies under the guidance of UPN. Analysis was done by NW and the manuscript was prepared by UPN. All authors read and approved the final manuscript.

\section{Acknowledgements}

Staff members in Soil Mechanics Laboratory, University of Moratuwa are kindly acknowledged for the support rendered in conducting experiments. Officials of Ceylon Electricity Board (CEB) and National Water Supply and Drainage Board (NWSDB), Sri Lanka are gratefully mentioned for releasing flyash and sludge for this study.

Competing interests

The authors declare that they have no competing interests.

Ethics approval and consent to participate

Not applicable.

\section{Publisher's Note}

Springer Nature remains neutral with regard to jurisdictional claims in published maps and institutional affiliations.

Received: 2 March 2017 Accepted: 22 January 2018

Published online: 26 January 2018

\section{References}

1. Ahmad T, Ahmad K, Alam M (2016) Characterization of water treatment plant's sludge and its safe disposal options. Procedia Enviorn Sci 35(2016):950-955

2. ASTM D 422 (1963) Standard test method for particle size analysis of soils. Annual book of ASTM standards. American Society for Testing and Materials, West Conshohocken

3. ASTM D 4318 (1983) Standard test method for liquid limit, plastic limit and plasticity index of soils. Annual book of ASTM standards. American Society for Testing and Materials, West Conshohocken

4. ASTM D 698 (1978) Standard test method for moisture-density relations of soils and soil-aggregate mixtures using 5.5-lb (2.49-kg) rammer and 12-in (305-mm) drop. Annual book of ASTM standards. American Society for Testing and Materials, West Conshohocken

5. ASTM D 854 (1983) Standard test method for specific gravity of soils. Annual book of ASTM standards. American Society for Testing and Materials, West Conshohocken

6. ASTM D 1883 (2007) Standard test method for CBR (California bearing ratio) of laboratory-compacted soils, Annual book of ASTM standards. American Society for Testing and Materials, West Conshohocken, pp 2-3

7. ASTM D 2487 (2011) Standard practice for classification of soils for engineering purposes (unified soil classification system). American Society for Testing and Materials, West Conshohocken

8. Bhuvaneshwari S, Robinson RG, Gandhi SR (2005) Stabilization of expansive soil using fly, Indian institute of Technology Madras, Chennai, 36 flyash utilization programme (FAUP), TIFAC, DST, New Delhi-110016

9. Brooks MR (2009) Soil stabilization with flyash and rice husk ash. Int J Res Rev 1(3):209-217

10. Cokca E (2001) Use of flyashes for the stabilization. J Geotech Geo Environ. 127:568-573

11. ICTAD (1989) Technical specification, vol 3. Colombo, ICTAD

12. Joshi RC, Lohtia RP (1997) Flyash in concrete: production, properties, and uses. Cord Res Sci, Amsterdam

13. Karim ME, Alram MJ, Hoque MS (2017) Effect of salinity of water in lime-flyash treated sand. Int J Geo Eng 8:15

14. Kim B, Prezzi M, Salgado R (2005) Geotechnical properties of flyash and bottom ash mixtures for use in highway embankments. J Geotech Geoenviron Eng 131(7):914-924

15. Kumar V (1996) Flyash utilization: a mission mode approach. Ash ponds and ash disposal systems. Narosa Publishing House, New Delhi

16. Lokeshappa B, Dikshit AK (2011) Disposal and management of flyash, 2011 International Conference on Life Science and Technology, vol 3. IACSIT Press, Singapore, pp 11-14

17. Nawagamuwa UP, Prasad DLS (2017) Improving soils of low CBR with flyash for road applications. In: Proceedings of the 19th international conference on soil mechanics and geotechnical engineering, Seoul 2017. pp 3393-3396

18. Phani Kumar BR, Sharma RS (2004) Effect of flyash on engineering properties of expansive soils. J Geotech Geoenviron Eng 130(7):764-767

19. Rodriguez NH, Ramirez SM, Varela MTB, Guille M, Puig J, Larrotcha E, Flores J (2011) Evaluation of spray-dried sludge from drinking water treatment plants as a prime material for clinker manufacture. Cem Concr Compos 33:267-275

20. Rogers CD, Glendinning S (1993) Modification of clay soils using lime. In: Rogers CA (ed) Proceedings of the seminar held at Loughborough University on lime stabilization. Thomas Telford, London, pp 99-114

21. Trinh TK, Kang LS (2011) Response surface methodological approach to optimize the coagulation-flocculation process in drinking water treatment. Chem Eng Res Des 89:1126-1135 